\title{
Unpacking Viazemskii's Khalat: The Technologies of Dilettantism in Early Nineteenth-Century Russian Literary Culture
}

Katherine Bowers

И, как боец свой плащ, простреленный в бою,
Я холю свой халат с любовью и почётом.* —P. A. Viazemskii (1877)

In Russa, certain garments carry important cultural connotations. The shinel', or overcoat, for example, is irrevocably tied to Nikolai Gogol"s clerk Akakii Akakievich. Similarly, the khalat, or dressing gown, evokes Ivan Goncharov's novel Oblomov (1859) and its hero's famously late lie-in. Writing about Oblomov's khalat, Richard Peace notes that the garment "comes to symbolize a whole attitude to life, and is ceremoniously donned or discarded according to altering circumstances and the hero's state of mind."

* "And, like a warrior his cloak, shot through in battle, I revere my dressing gown with love and respect." Excerpt from "Zhizn $<$ '> nasha v starosti-iznoshennyi khalat" (Our Life in Old Age is a Worn Dressing Gown), Polnoe sobranie sochinenii kniazia P. A. Viazemskogo (St. Petersburg, 1878-96; hereafter PSS), 12:549-550. All translations in this article are my own unless noted otherwise.

This research was conceived as part of the "Information Technologies in Russia, 1450-1850" project at the University of Cambridge, and I am thankful to Simon Franklin for his generous support and feedback throughout its many stages. This article has benefitted enormously from the suggestions of colleagues, among them Mel Bach, Connor Doak, Tatiana Filimonova, Ani Kokobobo, Muireann Maguire, John Carter McKnight, Harriet Murav, William Mills Todd III, Alexandra Vukovic, and the anonymous readers for Slavic Review. Thanks are also due to those who heard and discussed a version of 
Francine du Plessix Gray evocatively describes the khalat as "that greatest protective armor of the lethargic Russian male.”2 Oblomov's khalat remains such a powerful cultural image that it has been preserved in the word khalatnost', meaning "negligence" or "carelessness."33 Before Oblomov, however, the khalat played a significant, and different, role in the Russian cultural imagination. We see vestiges of this meaning in the epigraph above. Although written after Goncharov's novel, these lines take a different approach to the khalat. Comparing the dressing gown to a soldier's battle-worn cloak shows the garment to be beloved but also imbued with honor and respect. In the poem, Prince Petr Viazemskii refers to a khalat made famous sixty years earlier in the poem "Proshchanie s khalatom" (Farewell to My Dressing Gown) ${ }^{4}$

Viazemskii wrote "Proshchanie s khalatom" to lament his August 1817 appointment to government service in Warsaw. ${ }^{5}$ The poem quickly became popular within Arzamas, Viazemskii's this study at the In(s) and Out(s) Interdisciplinary Seminar Series at the University of Oxford in May 2013.

${ }^{1}$ Richard Peace, The Enigma of Gogol: An Examination of the Writings of N. V. Gogol and Their Place in the Russian Literary Tradition (Cambridge, Eng., 2009), 150.

${ }^{2}$ Francine du Plessix Gray, "The Russian Heroine: Gender, Sexuality, and Freedom," in Nicholas Delbanco, ed., Speaking of Writing: Selected Hopwood Lectures (Ann Arbor, 1990), 380.

${ }^{3}$ For a discussion of this preservation's particular nuances, see Aleksander Brückner, Literary History of Russia, trans. H. Havelock (London, 1908), 150.

${ }^{4}$ P. A. Viazemskii, "Proshchanie s khalatom," Stikhotvoreniia (Leningrad, 1986), 117-20. All quotes from the poem refer to this edition.

${ }^{5}$ This article only briefly treats episodes from Viazemskii's life. For a more thorough accounting of the poet's life and work, see Günther Wytrzens, Pjotr Andreevič Vjazemskij: Studie zur russischen Literaturund Kulturgeschichte des neunzehnten Jahrhunderts (Vienna, 1961); M. I. Gillel<'>son, P. A. Viazemskii: 
literary circle. ${ }^{6}$ Eventually, in 1821, "Proshchanie s khalatom" appeared in print. As the poem circulated during the period between its creation and printing, its central image— the khalat—became enshrined as a symbol for early nineteenth-century literary culture around and within the Arzamas circle, emphasizing a creative inner life and an informal approach to writing. The poem mediates between friendship, honor, authenticity, and authorship and the formalities, duties, and expectations of society life. In exploring the contextual boundaries and social mechanisms of literary reception surrounding "Proshchanie s khalatom," this article focuses particularly on the web of information technologies_-"speaking, writing, and printing"- that interacted as the center of Russian belles lettres shifted to the literary circle in the $1810 \mathrm{~s}$ zhizn<'> i tvorchestvo (Leningrad, 1969); and V. V. Bondarenko, Viazemskii (Moscow, 2004). For a biographical account of Viazemskii's departure for Warsaw and the dressing gown episode in particular, see ibid., 117-19.

${ }^{6}$ The Arzamas Society of Obscure People was a literary circle active mainly in St. Petersburg between 1815 and 1818. While the extent body of critical scholarship on Arzamas is enormous, I recommend a few key works. The classic studies are Iurii Tynianov, Arkhaisty i novatory (Leningrad, 1929); William Mills Todd III, The Familiar Letter: Literary Genre in the Age of Pushkin (Princeton, 1976); and M. I. Gillel<'>son, Molodoi Pushkin i arzamasskoe bratstvo (Leningrad, 1974) and Ot arzamasskogo bratstva k pushkinskomu krugu pisatelei (Leningrad, 1977). More recent studies include Alessandra Tosi, Waiting for Pushkin: Russian Fiction in the Reign of Alexander I, 1801-1825 (Amsterdam, 2006), esp. 44-102; and Mariia Maiofis, Vozzvanie k Evrope: Literaturnoe obshchestvo "Arzamas" i rossiiskii modernizatsionnyi proekt 1815-1818 godov (Moscow, 2008). Oleg Proskurin and Joe Peschio discuss the circle's culture of scandals and shocking language in Literaturnye skandaly pushkinskoi epokhi (Moscow, 2000) and The Poetics of Impudence and Intimacy in the Age of Pushkin (Madison, 2012), 34-59, respectively. For a collection of original Arzamasian documents (letters, speeches, protocols, poems, etc.), see Vadim Vatsuro and Aleksandr Ospovat, eds., “Arzamas”: Sbornik, 2 vols. (Moscow, 1994). 
and $1820 \mathrm{~s}^{7}$ In their literary output, experiments with production and dissemination, and mediation of artistic creation within the bounds of society life, Arzamas and similar literary circles became key components in the eventual rise of a literary profession in Russia. In this cultural context, Viazemskii's khalat and its echo and evolution in later works by poets such as Vasilii Zhukovskii, Anton Del'vig, and Aleksandr Pushkin remain a testament to the value placed on dilettante literary culture in the early nineteenth century.

This article does not claim to offer a comprehensive treatment of the khalat topos in Russian literary culture. For that, I direct readers to Stephanie Lee Merkel's study of the khalat as an artistic motif in Russian literary culture. ${ }^{8}$ As Merkel's study demonstrates, a structuralist approach to Viazemskii's khalat opens productive lines of inquiry, as the image's extratextual life complicates its basic symbolism. While structuralists position texts within their extratextual contexts in order to illuminate their meaning, in examining the khalat image — both inter- and extratextually—-through the prism of meme theory, I demonstrate the evolutionary quality of this meaning. ${ }^{9}$

${ }^{7}$ I use information technologies as Simon Franklin does in "Mapping the Graphosphere: Cultures of Writing in Early 19th-Century Russia (and Before)," Kritika 12, no. 3 (Summer 2011): 531-60. Examining literary and intellectual writing in the first half of the nineteenth century, Franklin broadly discusses "the three communicative technologies of speaking, writing, and printing." Ibid., 532. Information technology goes beyond the graphosphere to encompass modes of information dissemination that interact with it. It is in this sense that I use the term here and elsewhere in this study.

${ }^{8}$ Stephanie Lee Merkel, “The Romantic Culture of Xalatnost<'>: From P. A. Viazemskii to I. A. Goncharov" (PhD diss., Cornell University, 1998).

${ }^{9}$ See, for example, Jurij Lotman, The Structure of the Artistic Text, trans. Gail Lenhoff and Ronald Vroon (Ann Arbor, 1977). As Lotman observes, "The entire sum of historically determinate artistic codes that make a text meaningful is related to the sphere of extra-textual relations" (50). 
The present study presents the khalat as an early nineteenth-century meme, a circulating image with an evolving, embedded meaning. ${ }^{10}$ In this context, unpacking Viazemskii’s khalat—semantically, symbolically, historically, and culturally—gives insight into the links between authorship, the literary circle, readership, and early nineteenth-century information transfer. I examine the poem and its image in three contexts: the original poem and its intertextual connections, extratextual circulation, and the image's memetic development. Looking at Viazemskii's khalat across these three areas highlights the culture of dilettante-authorship within the literary circle and broader society life but also naturally lends itself to a discussion of the function of early nineteenth-century literary-circle technological production, from creation to dissemination and, finally, to printing. ${ }^{11}$

${ }^{10}$ I rely on meme theory from its inceptive meanings: first, biologist Richard Dawkins's original definition in The Selfish Gene (Oxford, 1976) of a meme as the cultural equivalent of a gene (189-201); then, the work of psychologist Henry Plotkin, Darwin Machines and the Nature of Knowledge (Cambridge, Mass., 1993). Plotkin observes that a meme not only is a cultural replicator but also carries an evolutionary element. Ibid., 215-18, 222-26.

${ }^{11}$ On literary dilettantism as a European cultural phenomenon, see Richard Hibbitt, Dilettantism and Its Values: From Weimar Classicism to the Fin de Siècle (Oxford, 2006). Hibbitt discusses the concept of dilettantism as referring to six activities: “amateurism, apprenticeship, 'bodging,' plagiarism, aestheticism, and skepticism." Ibid., 168. Hibbitt's research stems from models put forward by Friedrich Schiller and Johann Wolfgang von Goethe and their evolution through the end of the century. Early nineteenth-century Russian dilettantism, on the other hand, seems to have associations mainly with amateurism, apprenticeship, and aestheticism. It is in this sense of nonprofessionalism that I refer to "dilettantism" here and throughout. Viazemskii himself called A. I. Turgenev a "dilettante" and meant the term in a positive sense. Viazemskii, PSS, 8:276-80. 
Dilettantism thrives on informal literary expression and dissemination, but the interaction of information technologies within this historical and cultural context aid our understanding of the literary circle as a highly developed intellectual network. Randall Collins's theory of intellectual networks underscores the relationship between information technologies, transfer, and the network. ${ }^{12}$ Collins posits that sophisticated ideas are formed within social locations, that is, meetings involving discussion and information transfer, which in turn create a social network pattern. Intellectual networks are the result of small groups and discussion and create their own culture, propagated by exchange and informed by network memory. ${ }^{13}$ Tracing the intertextual, extratextual, and memetic evolution of a significant concept like Viazemskii's khalat demonstrates the way that network culture is created through information exchange.

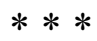

Viazemskii's poem presents an idealized version of the informal literary process and dilettantism valorized by the Arzamasians and contrasts it with the formality of early nineteenth-century society life. Throughout "Proshchanie s khalatom," the khalat remains a central image, always signaling authenticity and inspiration for the poet. The opening lines refer to the dressing gown as a friend and comrade, but the garment becomes much more, ultimately transforming into a uniform the poet can wear both to safeguard his authentic self and to facilitate the creative process. In addition to this meditation on the dressing gown, reading the poem within its frame of reference provides insight into notions about early nineteenthcentury literary process. Viazemskii's verse presents a wide array of intertextual references, the

${ }^{12}$ Randall Collins, The Sociology of Philosophies: A Global Theory of Intellectual Change (Cambridge, Mass., 1998), 19-74. Collins argues for a general theory of intellectual life built on the anthropological concept of "interaction ritual," from the theories of Émile Durkheim, George Herbert Mead, and Erving Goffman.

${ }^{13}$ Ibid., 25-28. 
exploration of which exposes the ideas that poets themselves held about poetic life in the early nineteenth century.

The poem begins with an address to its central image and immediately establishes the contrast between society life and private life.

Прости, халат! товарищ неги праздной, Досугов друг, свидетель тайных дум!

С тобою знал я мир однообразный, Но тихий мир, где света блеск и шум Мне в забытьи не приходил на ум. Искусства жить недоучённый школьник, На поприще обычаев и мод, Где прихоть-царь тиранит свой народ, Кто не вилял? В гостиной я невольник, В углу своём себе я господин, Свой меря рост не на чужой аршин.

(Farewell, khalat! comrade of idle bliss, / Friend of leisure, witness of secret thoughts! / With you I knew a monotonous world / But a quiet world, where the glitter and noise of society / Never entered my mind when I was in oblivious slumber. / Which callow schoolboy of the art of living, / On the field of fads and fashions, / Where Tsar Caprice tyrannizes his people, / Hasn't dithered? In the drawing room I am a slave, / But in my own corner, I am my own master, / Measuring my height by my own measuring tape.)

The semantic contrast of the rhymed words um (mind), dum (thoughts), and shum (noise) underscores the private/society contrast but at the same time shows how the two separate worlds must at times function as 
a single whole. Although this opening seems to simply emphasize the binaries and hierarchies that run throughout the poem, these lines also carry with them an answer to the question: why did Viazemskii choose the khalat?

First, the garment stands in stark contrast to formal dress and provides a lighthearted poetic subject, one far removed from lofty neoclassical subjects. From the poem's first words, addressing the khalat, the reader senses the work's inherent humor. The dressing gown's whimsy as both material object and poetic addressee allows for language play throughout the poem related to tailoring and fashion. For example, in the last lines, the Russian word arshin is a unit of measure (equal to $71.12 \mathrm{~cm}$ ) particularly associated with tailoring, so while Viazemskii's poet is his own master, and measures his own height, he does this with a tailor's tool. My translation of it as "measuring tape" is inexact but emphasizes this sartorial connection. Similarly, the tsar who terrorizes his people in these lines is a "prikhot'-tsar'," a tsar of caprice, linked to frivolity, fads, and fashions.

In addition to its connotations of leisure and informality, the dressing gown carried a cultural meaning adopted from French literary culture. Nearly fifty years before Viazemskii wrote "Proshchanie s khalatom," Denis Diderot wrote an essay in which he ruminates about his dressing gown's loss, "Regrets sur ma vieille robe de chamber, ou Avis à ceux qui ont plus de goût que de fortune" (Regrets for My Old Dressing Gown, or A Warning to Those Who Have More Taste Than Fortune) (1769). ${ }^{14}$ In the essay, Diderot juxtaposes the comfort he felt in his shabby old dressing gown with the discomfort of a stiff,

${ }^{14}$ Denis Diderot, "Regrets sur ma vieille robe de chambre, ou Avis à ceux qui ont plus de goût que de fortune," Euvres de Diderot, ed. André Billy (Paris, 1951), 953. Viazemskii translated Diderot's essay in 1821, four years after writing "Proshchanie s khalatom," but given the references to it here, it is likely he read it earlier. On the Diderot essay and Viazemskii's unpublished translation, see V. Stepanovich, “Frantsuzskie prosvetiteli XVIII veka v perevodakh Viazemskogo,” Russkaia literatura, no. 3 (1966): 8889. 
starchy new robe, using the two as a metaphor for the importance of authenticity for creativity and generally. ${ }^{15}$ Viazemskii's contrast between slave and master echoes Diderot, who writes, "I was the absolute master of my old dressing gown; now I am the slave of my new one."16 In "Proshchanie s khalatom," Viazemskii expands on Diderot's dichotomy, however, comparing a schoolboy and a tsar, a slave and a lord.

In “Regrets sur ma vieille robe de chambre,” Diderot's new dressing gown becomes a disdained sign of his success in society, whereas the worn old robe represents the creative life: "[Its] long lines announce the litterateur, the writer, the man who works. I now have the air of a rich good-for-nothing. No one knows who I am." ${ }^{17}$ This notion of dressing gown as poetic uniform also has a precedent in another early nineteenth-century Russian poem. Konstantin Batiushkov's "Videnie na beregakh Lety" (A Vision on the Banks of the River Lethe, 1809) depicts a poet clad in a shlafrok, another term for dressing gown prevalent at this time (a borrowing from German). ${ }^{18}$ The shlafrok marks the poet Krylov as a genuine

${ }^{15}$ On the historical interpretation of Diderot's essay, see Jane B. McLelland, "Changing His Image: Diderot, Vernet and the Old Dressing Gown," Diderot Studies 23 (1988): 129-41. For more on the historical context of the essay, see Samuel Sadaune, “L'Ouverture excentrique du Salon de 1769 ou portrait du Philosophe en robe de chambre," Recherches sur Diderot et sur l'Encyclopédie 35 (October 2003): 7-23.

${ }^{16}$ Diderot, "Regrets sur ma vieille robe de chamber," 953.

${ }^{17}$ Ibid., 953. Sadaune also comments on Diderot's notion of dressing gown as uniform, showing the development of the robe de chambre image in the Correspondance littéraire. Sadaune, "L'Ouverture excentrique du Salon de 1769," 7-8.

${ }^{18}$ K. N. Batiushkov, Polnoe sobranie stikhotvorenii (Moscow, 1964; hereafter PSS), 94-102. In a response to Batiushkov's poem, following a chain of epistolary verse, Pushkin's 1815 poem "K Galichu" (To Galich) replaces the "shirokii shlafrok" (large dressing gown) with a "tatarskii khalat" (Tatar dressing 
artist, but his dishabille also lends him a more intimate, whimsical air, more conducive for creativity, just as it does for Diderot. From its early meditation on the old dressing gown's utility and comfort, Diderot's essay quickly diverges into a reflection on aesthetics, whereas Viazemskii's poem continues to explore the notion of khalat as poetic uniform, in the vein of Diderot and Batiushkov. From the opening lines, Viazemskii's poet is marked as an authentic litterateur.

As "Proshchanie s khalatom" progresses, the poet contrasts one emblematic mode of dress with another, bringing in a broader expression of the documented tension between public and private—or creative and societal-life in early nineteenth-century Russia. ${ }^{19}$ The next lines contrast the khalat with a "slave's bonds" but also with formal society evening dress, costumes that serve here as uniforms denoting social status.

Как жалкий раб, платящий дань злодею,

И день и ночь, в неволе изнурясь,

gown). A. S. Pushkin, Polnoe sobranie sochinenii v shestnadtsati tomakh (Moscow, 1937-59; hereafter PSS), 1:121-22. Merkel discusses this exchange at length. See Merkel, "The Romantic Culture of Xalatnost<'>," 135-49.

${ }^{19}$ The tension between public and private life in the early nineteenth century has been a topic of discussion for scholars since Boris Eikhenbaum's seminal essay “Literaturnaia domashnost<’>” (1929). Recent studies that problematize and discuss this tension include Andreas Schönle, "The Scare of the Self: Sentimentalism, Privacy, and Private Life in Russian Culture," Slavic Review 57, no. 4 (Winter 1998): 726-48; Andrei Zorin, “Pokhod v bordel<’> v Moskve v ianvare 1800 goda (Shiller, gonoreia i pervorodnyi grekh v emotsial<'>nom mire russkogo dvorianina)," Novoe literaturnoe obozrenie 92 (2008): 142-57; Peschio, The Poetics of Impudence, 14-24; and Andrew Kahn, "Life Writing in the 1830s: Viazemsky’s Fon-Vizin and Pushkin’s ‘Table Talk,”' Ulbandus 12 (2009-10): 83-104. 
Вкушает рай, от уз освободясь,

Так, сдёрнув с плеч гостиную ливрею

И с ней ярмо взыскательной тщеты,

Я оживал, когда, одет халатом, ${ }^{20}$

(Like a pathetic slave, indentured to a villain, / Day and night beleaguered in servitude, / He tastes paradise, freeing himself of bonds, / As, removing formal dress from my shoulders, / And with it the yoke of exacting futility, / I revived, when, dressed in my khalat, / I once more reconciled with my abandoned Penates;)

"Gostinaia livreia" (literally "reception-room livery") is a specifically prescribed mode of formal evening dress, a uniform for high society events, whereas the khalat is worn only in informal, private spaces. For the poet, who prefers the freedom afforded by his khalat, a slave's bonds and a prince's evening dress merge semantically; neither is desirable as both represent service to others. He implicitly conflates the social hierarchy that dictates his public role with the slave's villainous master. Although the khalat is a seemingly frivolous garment, in this transitional environment where the poor and wealthy are equally enslaved, it allows the poet freedom. Regardless of one's social rank—general, prince, or clerk—the khalat serves as an equalizer, denoting its wearer's place in a private, domestic setting. The rhymed pairs here- the words zlodeiu (villain) and livreiu (livery) and, contrastingly, khalatom (dressing gown) and Penatom (Penates)—emphasize this point.

${ }^{20}$ The particular image of the Penates, the Roman hearth spirits, evokes Batiushkov's 1811 poem "Moi penaty" (My Penates), which bears the subtitle "K Zhukovskomu i Viazemskomu" (To Zhukovskii and Viazemskii). The poem is a meditation on the comfort of private life and solitude. Batiushkov, PSS, 13441. On the Penates and their place in early nineteenth-century Russian poetic culture, see Ingrid Kleespies, "Traveling Domestics: The Penates and the Poet in Pushkin's Lyric Verse," Pushkin Review Vol. 15 (2012): n.p. 
Additionally, as in Diderot's essay, the khalat proves conducive to the literary process in "Proshchanie s khalatom." Donning the garment serves to shift the poet's mind's focus from the external to the internal and directly sparks his creative energies.

\section{Минувшего проснувшиеся тени}

В прозрачной тьме толпилися вокруг;

Иль в будущем, мечтаньем окриленный,

Я рассекал безвестности туман,

Сближая даль, жил в жизни отдаленной

И, с истиной перемешав обман,

Живописал воздушных замков план.

Как я в твоём уступчивом уборе

В движеньях был портного не рабом,

Так мысль моя носилась на просторе

С надеждою и памятью втроём.

(Awakened shades of past times / Crowded around in transparent gloom; / Or in the future, taking flight with dreams, / I cut through the mist of the unknown, / Drawing near the distance, I lived a distant life / And, blending deception with truth, / I painted a plan of castles in the air. / Just as I in your unrestrictive drapery / In my movements was no slave to the tailor, / So too did my mind roam freely / Together with hope and memory.)

This near-fantastic description of the poet-speaker's thoughts encompasses vast distances, moving easily between past and future and across space, expanding his environment effortlessly from the local, closed spaces of the previous lines. The rhyme of "taking flight" (okrylennyi) with "distant" (otdalennyi) particularly emphasizes this conflation of motion and imagination; the word okrylennyi literally means 
"bewinged" but also carries the meanings of "inspired" and "propelled." Although inherently unsustainable, the ephemeral "airy castles" the poet creates speak to the power of his artistic enterprise and present a stark contrast to the monotony that characterizes society life.

The rhyme of plan and obman (deception) suggests that poetic imagination is divorced from reality, but in the next lines, the khalat once again grounds the poet, bringing him back to authenticity; the tone abruptly shifts to a light-hearted reminder of the dressing gown's utility. Here, the poem once more echoes Diderot's essay. Just as Viazemskii's poet is unrestricted by his khalat, and freed from dependence on the tailor, Diderot writes of how his old robe de chambre provided physical and metaphysical relief, not inhibiting his body while freeing him from the anxiety of formal dress and dependence on a valet: "It molded itself to all the contours of my body without inhibiting it; I was picturesque and handsome. ... In its shelter, I feared neither the clumsiness of a valet, nor my own." ${ }^{21}$ Diderot's robe de chambre becomes animate here, just as Viazemskii's khalat is personified through use of the word ustupchivyi (unrestrictive).

As these lines conclude, Viazemskii's poet similarly associates the dressing gown with freedom; not only does his khalat promote physical freedom, it also becomes a symbol of metaphysical freedom. Freedom here is an idealized concept, incorporating freedom from society, freedom from duty, and artistic freedom. These freedoms are inextricably bound together from the poem's inception and also covertly suggest political freedom. As the dressing gown acquires meanings - an antidote to official court dress, the subversion of social convention, opposition to the tsar (even a whimsical tsar of caprice) - it becomes an alternative costume to the official uniform bound up with the status quo. Even the poem's title juxtaposes Viazemskii's khalat and his official uniform: he bids his dressing gown farewell to take up a government post. While the khalat accommodates this political meaning (and its development will be

${ }^{21}$ Diderot, "Regrets sur ma vieille robe de chamber," 953. 
revealed in due course), in "Proshchanie s khalatom" the poet's primary focus is not on the political but on the creative and artistic.

The dressing gown uniform indeed proves useful to the poet's artistic enterprise. His khalat not only spurs him on to great poetic activity, it also strengthens the poet's bond with his Muse. Again, the poet sets notions of labor, work, and society life against his internal, creative process.

Шёл прямо я к столу, где Муза с лаской

Ждала меня с посланьем или сказкой

И вымыслом, нашёптанным вчера.

Домашний мой наряд ей был по нраву:

Приём её, чужд светскому уставу,

Благоволил небрежности моей.

Стих вылетал свободней и простей;

Писал шутя, и в шутке легкокрылой

Работы след улыбки не пугал.

(I went directly to my desk, where the Muse with tenderness / My domestic attire was to her liking: / Her greeting, alien to social codes, / Favored my informality. / My verses flowed, freely and simply; / I wrote jokingly, and in the light-winged jest / The trace of labor did not frighten away my smile.)

In the poetic tradition, the worshipful poet lauds the Muse as a near-goddess; in Gavriil Derzhavin's " $\mathrm{K}$ muze" (To the Muse, 1797), for example, she appears from heaven accompanied by golden harps and birdsong. ${ }^{22}$ Pushkin famously plays with this notion in chapter 7 of Evgenii Onegin, in which he makes a point of remarking that he has "paid homage to classicism" (klassitsizmu otdal chest') by invoking the

${ }^{22}$ G. R. Derzhavin, Stikhotvoreniia (Leningrad, 1957), 250-51. 
"epic muse" (epicheskaia muza). ${ }^{23}$ In "Proshchanie s khalatom," the poet invokes a different kind of muse, one that resonates with the new poetry.

Viazemskii's poet stresses the Muse's informality, her foreignness to society. Additionally, aided by her favor, the poetic craft becomes divorced from the sphere of labor and, instead, is described as "free," "simple," "flowing," and even "joking." This description aligns with others found in poetry from this time. Batiushkov, for example, writes of a lazy muse (lenivaia muza) in his late 1809 or early 1810 satirical poem "P. A. Viazemskomu" (To P. A. Viazemskii) and goes on to describe how the muse laughs at the poet and tricks him into forgetting the poetry he is writing. ${ }^{24}$ Batiushkov's satirical muse is so informal she actually undermines the creative process. Similarly, Evgenii Baratynskii's 1830 poem "Muza" (The Muse) complicates the traditional attitude of veneration towards her. Baratynskii's poet is "not dazzled by [his] muse" (ne osleplen ia muzoiu moeiu); instead, he valorizes her "unique expression" (neobshchim vyrazhen'em) and the "calm simplicity" (spokoinoi prostotoi) of her speech. ${ }^{25}$

In "Proshchanie s khalatom," the description of the writing process again manifests the vivacious humor that characterizes the piece but also the poet's earnest joy in his light-hearted artistic creation. Phonetic pairs such as the assonance of pero (pen) and legko (easy) and the encircling rhyme of "inspiration" (vdokhnovennyi) with "pleasure" (naslazhdennyi) show the association of poetry with ease and leisure. The informality of the muse and the writing process in this passage serve to contrast with the muse described in the next.

In the lines immediately following, the poet contrasts his idealized, informal mode of poetic creation with that of a dandy poet, comparing their muses and writing processes. In the early nineteenth century, "dandy" described a man who placed particular importance on fashion, physical appearance, and

${ }^{23}$ Pushkin, PSS, 6:164.

${ }^{24}$ Batiushkov, PSS, 245-46.

${ }^{25}$ E. A. Baratynskii, Polnoe sobranie stikhotvorenii v dvukh tomakh (Leningrad, 1936), 1:156. 
cultivating an air of nonchalance. ${ }^{26}$ The "dandy poet," similarly, embraces the poses and acts of dandyism as part of his literary modus operandi. His poetic art is meaningless and characterized by the façade with which he surrounds himself. ${ }^{27}$

Как жалок мне любовник муз постылый, Который нег халата не вкушал!

${ }^{26}$ See the description of Onegin's dandyism. Pushkin, PSS, 6:6-7. In the commentary to his translation of Evgenii Onegin, Vladimir Nabokov describes a dandy as "an exquisite" or "a swell" but argues that Onegin is more like a "beau" in the sense of Beau Brummel than a "dandy." See Aleksandr Pushkin, Eugene Onegin: A Novel in Verse, Translated from the Russian with a Commentary by Vladimir Nabokov, 4 vols. (London, 1964), 2:43-45. Here, however, I mean the original form of late eighteenth- and early nineteenth-century dandyism, which Thomas Carlyle neatly sums up in the following statement from his musings on "The Dandiacal Body": "A Dandy is a clothes-wearing Man, a Man whose trade, office and existence consists in the wearing of Clothes. Every faculty of his soul, spirit, purse, and person is heroically consecrated to this one object, the wearing of Clothes wisely and well: so that the others dress to live, he lives to dress." Thomas Carlyle, Sartor Resartus: The Life and Opinions of Herr Teufelsdröckh in Three Books, ed. by Mark Engel (Berkeley, 2000), 200. For more information on historical and literary dandies, see Ellen Moers, The Dandy: Brummell to Beerbohm (London, 1960).

${ }^{27}$ This earlier type of dandy poet predates the more prevalent modernist incarnation. The term "dandy poet" is typically associated with modernist figures reflecting views of the dandy established by Charles Baudelaire and Albert Camus and keeping in the vein of Jules-Amédée Barbey d'Aurevilly, whose 1845 study Du dandysme et de George Brummel established dandyism as a philosophy of being. On modernist dandy poets, see Jessica Feldman, Gender on the Divide: The Dandy in Modernist Literature (Ithaca, 1993), 13-14; and Rita Felski, The Gender of Modernity (Cambridge, Mass., 1995), 91. 
Поклонник мод, как куколка одетый

И чопорным восторгом подогретый,

В свой кабинет он входит, как на бал.

Его цветы-румяны и белила,

И, обмакнув в душистые чернила

Перо своё, малюет мадригал.

Пусть грация жеманная в уборной

Дарит его улыбкою притворной

За то, что он выказывал в стихах

Слог расписной и музу в завитках.

(How pitiful to me is the Muse's odious suitor / Who has never experienced the dressing gown's blisses! / He is a slave to fashion, dressed like a doll / And warmed with prim excitement, / He comes into his study as if entering a ball. / His flowers are rouge and white powder, / And, dipping his pen / Into perfumed ink, he drafts a madrigal. / Let some simpering grace in her chamber / Give him an artificial smile / Because he displayed in his poems / Decorative verse and a muse in ringlets.)

The dandy poet, in the thrall of fashion, comes to his study to write as if entering a ball: starched, rouged, and powdered, his ink perfumed. These indicators of artificiality doom his literary efforts, just as his conscious sartorial ensemble repulses the Muse. Associating particular types of writing with particular choices of dress, "Proshchanie s khalatom" visits another aspect of the poetic uniform. Dandyism here becomes a metaphor for poetry, for one's attitude to life, just as the comfort and informality of the dressing gown has been established as another perspective on poetic creation. 
The dandy poet's artificiality is reflected in his art form: he writes a madrigal, a form of secular song that hierarchizes and formalizes passions such as love. ${ }^{28}$ For Viazemskii’s poet, genuine feeling of expression is not possible with a muse wearing her hair in ringlets, whose artificiality elicits only "decorative" (raspisnoi) verse. The dandy poet's muse is opposed to Viazemskii's Muse in nearly all regards, and, as a result, the poetry produced is equally opposite: inauthentic and dictated by society. While the dandy poet appears as a figure of derision in "Proshchanie s khalatom," he also serves to divorce the literary circle from structures more closely tied to society life such as the imperial court or the salons. The dandy poet produces verse for a wealthy patron or salon hostess; his motivations include fashion and prestige.

"Proshchanie s khalatom" juxtaposes the dandy poet's example with Anacreon, offering the Greek poet up as an ideal creative model in the next lines. ${ }^{29}$ Anacreon appears the polar opposite of the artificial, formal, and well-coifed dandy poet.

28 "Musical genres" of poetry were popular in the early nineteenth century, and writers such as Zhukovskii and Del<'>vig were fond of them. Originally introduced into the Russian canon by Vasilii Trediakovskii, these genres were associated with eighteenth-century models of poetry. Pushkin scorned them, writing only one madrigal himself ("Madrigal M . . oi," 1817-20), and then putting a "poshlyi" (trite) madrigal in Onegin's mouth in Evgenii Onegin, chapter 5. See also Thomas Hodge, A Double Garland: Poetry and Art-Song in Early-Nineteenth-Century Russia (Evanston, 2000), 3-24.

${ }^{29}$ Anacreon's poetry was popular in the eighteenth century and beyond and was both emulated and imitated. On Anacreon, his popularity in Russia, and the eighteenth-century literary tradition of “anakreontika," see C. L. Drage, “The Anacreontea and 18th-Century Russian Poetry,” Slavonic and East European Review 41 (1963): 110-34. 
Но мне пример: бессмертный сей неряха-

Анакреон, друг красоты и Вакха,

Поверьте мне, в халате пил и пел;

Муз баловень, харитами изнежен

И к одному веселию прилежен,

Играя, он бессмертие задел.

(But for me the example is: that immortal slovenly fellow_- Anacreon, friend of beauty and Bacchus, / Who, believe me, drank and sang in his dressing gown; / The Muses' favorite, pampered by the Charities / And disposed only to gaiety, / Playing, he brushed against immortality.)

In "playing," or entirely giving up formalities, he spontaneously and seemingly effortlessly achieves artistic greatness. In using the word "zadel” (brushed), Anacreon's immortality becomes almost an afterthought. The importance of the Greek poet's example is his writing process, his eschewal of society's opinion with its attendant rules and formalities. Significantly, Anacreon appears drinking and singing in his dressing gown.

Viazemskii's image of Anacreon in a khalat revitalizes a trope appropriated by earlier poets. ${ }^{30}$ Derzhavin's Anakreonticheskie pesni (Anacreontic songs, published 1804) was an influential work for the

${ }^{30}$ Luba Golburt discusses the way that the eighteenth century manifests in the early nineteenth-century Russian cultural imagination in "Catherine's Retinue: Old Age, Fashion, and Historicism in the Nineteenth Century," Slavic Review 68, no. 4 (Winter 2009): 782-803. Golburt begins with Ivan Kireevskii's essay "Deviatnadtsatyi vek" (The Nineteenth Century, 1831), in which she identifies two historicist premises: "The Hegelian notion that each person can be understood as a product of a specific Zeitgeist and the idea that a conglomeration of historical planes constitutes the novelty of nineteenth- 
poets of Viazemskii's generation. Viazemskii's Anacreon sharply contrasts with the frontispiece engraving of Derzhavin's volume, which depicts Anacreon's bust with a lyre artfully leaned against its pedestal, evoking classicism. Similarly, Pushkin's poem “Grob Anakreona” (The Grave of Anacreon, 1815) appropriates and transforms the older model provided by Goethe in "Anakreons Grab" (Anacreon's Grave, 1785). ${ }^{31}$ Goethe's poem uses dactylic hexameter, lending it a more classical feel, and explores the discovery of a tomb forgotten by humans but honored by the gods of nature; emphasizing the classical subject, Goethe placed the poem originally in a collection called Antiker Form sich nährend (Approaching Antique Form). Pushkin's poem, on the other hand, updates the meter to trochaic tetrameter and changes the episode's focus to a man's feelings on encountering Anacreon's tomb.

Continuing in this vein, Viazemskii's poet-speaker in "Proshchanie s khalatom" compares his own position to Anacreon's, again emphasizing the Greek poet's informality.

Не льщусь его причастником быть славы, Но в лени я ему не уступлю:

Как он, люблю беспечности забавы, Как он, досуг и тихий сон люблю.

(I don't aspire to be his equal in glory, / But in laziness I'm his equal: / Like him, I love carefree entertainment, / Like him, I love my leisure and quiet dream.)

century experience, of its own Zeitgeist" (785). For the extension of this argument, see Luba Golburt, The First Epoch: The Eighteenth Century and the Russian Cultural Imagination (Madison, 2014).

${ }^{31}$ Pushkin, PSS, 1:165-66; Goethes Sämtliche Werke: Briefe, Tagebücher und Gespräche. vol. 1, Gedichte 1756-1799, ed. Karl Eibl (Frankfurt am Main, 1987), 336. 
Although Anacreon achieved poetic greatness, the poet characterizes shared elements of their writing process not as work but as "leisure" (dosug), "carefree entertainment" (bespechnosti zabavy), and even "laziness" (len'). The juxtaposition of glory and laziness - and the notion that Anacreon's glory directly resulted from his laziness - adds a note of humor but also reinforces the notion of how the Arzamasian poets, such as Viazemskii and Vasilii Pushkin, thought about their own craft, or, at least, wanted to give the appearance of doing so. For them, writing and literary process was a leisure activity and a source of internal pleasure away from the stresses and distractions of external society life.

While Arzamas's foundation has recently been revealed as politically motivated, the gatherings also led to a culture that privileged this internal life and view of literature. ${ }^{32}$ As "Proshchanie s khalatom" concludes, for Viazemskii, it is this interior, informal life - the creative life of the mind - that ultimately triumphs.

Сокровище благ прежних возврати;

Дай радость мне, уединясь с тобою,

В тиши страстей, с спокойною душою

И не краснев пред тайным судиёю,

Бывалого себя в себе найти.

Согрей во мне в холодном принужденье

Остывший жар к благодеяньям муз,

${ }^{32}$ Maiofis's study, Vozzvanie k Evrope, emphasizes Arzamas's reformist political aims and engagement from its inception. While the notion of the group as a band of friendly compatriots engaging in dilettantish literary production is reinforced through the "fascinatingly frivolous" Arzamasian protocols (Todd, The Familiar Letter, 50), it is precisely through this informality and rejection of hierarchy that the circle's political activities took root, as Maiofis argues. 
И гений мой, освободясь от уз,

Уснувшее разбудит вдохновенье.

Пусть прежней вновь я жизнью оживу

И, сладких снов в волшебном упоенье

Переродясь, пусть обрету забвенье

Всего того, что видел наяву.

(Return the treasure of former bliss; / Give me joy, again cloistered with you, / In the quiet of passions, with a peaceful soul, / Unblushing before my private judge, / To find my old self within myself. / Rekindle within me the fire for the beneficence of the muses / That had cooled because of cold compulsion, / And then my genius, free of bonds, / Will awaken sleeping inspiration. / Let me live again my life as before / And, born anew in magic raptures / Of sweet dreams, let me forget / All that I have seen in wakefulness.)

Here "Proshchanie s khalatom" brings in other poems that privilege the life of the mind, such as Batiushkov's "Moi genii" (My Genius, 1815) and "P. A. Viazemskomu," which similarly feature the rhymed pair $m u z$ (muses) and $u z$ (bonds). ${ }^{33}$ Batiushkov's "Moi genii" is a meditation on inspiration, and it concludes with the image of inspiration occurring to the sleeping poet-speaker. Batiushkov's poet is, thus, the ultimate dilettante, unconsciously entering into poetic reverie even in sleep. In a twist, the conclusion of "Proshchanie s khalatom" calls on "sleeping inspiration" to revisit the poet. While his inspiration slumbers, literary process and internal creative life conflate and become a privileged and desired state, one reached from within the folds of the khalat.

"Proshchanie s khalatom" typifies Arzamasian banter and whimsy and takes a seemingly frivolous topic as its subject, but under the surface, it presents a more serious meditation on authenticity in art and the role of the poet in society. The work becomes a manifesto for the poet-dilettante and for a specific

${ }^{33}$ Batiushkov, "Moi genii,” PSS, 192; “P. A. Viazemskomu,” PSS, 245-246. 
type of literary process, divorced from fad and fashion yet subject to political caprice and societal event, valorizing the particular blend of informality, freedom, and creativity that defined Arzamas artistically while ruminating on the experience of literary process. As this meaning-embedded in the poetic image of the khalat—evolved through memetic circulation, it came to inform Russian romantic culture and literary life, and, at the same time, to represent it.

Viazemskii’s poem describes an idealized literary life during the key period between eighteenth-century court or salon culture and the rise of a literary profession in the 1830s and '40s. ${ }^{34}$ Examining the khalat's extratextual life within its historical and cultural context provides a single example of transmission and circulation within the literary-circle network, exposing the information technologies that enabled dilettante poetic culture. Furthermore, tracing the memetic life of Viazemskii's khalat through the web of interacting technologies reveals Arzamas's scope as an intellectual network that created long-lasting traceable network memory and reached beyond the circle's limited rosters. ${ }^{35}$

For the Arzamasians, letters were a key technology; the individual members' far-flung duties and responsibilities meant that only a fraction were in attendance at any given event. Information traveled by familiar letter, and the Arzamasian correspondence played an important role in propagating the circle's unique culture as well as bonding the group more closely together. ${ }^{36}$ When his poem was read at the areopagus in St. Petersburg, Viazemskii was absent. He heard about its reception second-hand, in

${ }^{34}$ For more about this shift and the dynamic between patronage, society, and familiar circles during the transition, see William Mills Todd, III, Fiction and Society in the Age of Pushkin: Ideology, Institutions, and Narrative (Cambridge, Mass., 1986), 51-65.

${ }^{35}$ On the intellectual network and network memory, see Collins, The Sociology of Philosophies, 25-28. ${ }^{36}$ On the familiar letter, its genre, and its importance for Russian literary culture, see Todd, The Familiar Letter, $38-75$ and $134-55$. 
Moscow. Writing to Aleksandr Bulgakov in a letter dated October 2, 1817, Turgenev mentions that Viazemskii's verses have been read at Arzamas and asks Bulgakov to convey this news to Viazemskii, along with another message. ${ }^{37}$ Additionally, in a letter to Viazemskii dated October 5, Turgenev mentions the poem's favorable reception and tells his friend that Zhukovskii is coming to Moscow with a full report. ${ }^{38}$ Typically, Turgenev would write to Viazemskii to let him know about his work's reception if read in absentia, and a number of letters containing information like this exist in the two friends' collected correspondence. ${ }^{39}$ The Arzamasian correspondence surrounding "Proshchanie s khalatom" reveals a

37 Turgenev writes, “Скажи, любезный друг, Вяземскому, что 1000 р. на карету и письмо его получил; завтра обо всем справлюсь. Сегодня прочел и восхитил Арзамас его халатом” (My dear friend, tell Viazemskii that I received his letter and 1000 rubles for the carriage; tomorrow I'll arrange everything. Today I read and enraptured Arzamas with his khalat). A. I. Turgenev, Pis $<^{\prime}>m a$ Aleksandra Turgeneva Bulgakovym, 161.

38 Turgenev writes, “Я получил два письма твои и прекрасный ‘Халат’ твой, в котором ты явился нам со всею прекрасною душою твоею. Жуковский, отправившийся вчера в Москву, перескажет тебе о чтении послания в Арзамасе" (I received two of your letters and your splendid "Khalat," in which you appeared to us with your entire splendid soul. Zhukovskii, who set off for Moscow yesterday, will tell you about the reading at Arzamas). P. A. Viazemskii, Ostaf<'> evskii arkhiv kniazei Viazemskikh (St. Petersburg, 1899), 1:89.

${ }^{39}$ On September 18, 1817, for example, Turgenev writes to Viazemskii about a different poem read at a different Arzamas gathering: “Стишки ваши прочтены в Арзамасе в самый день получения; а сегодня, в прощальном Арзамасе у Черного Врана, сообщу ваше последнее поносное отношение” (Your little verses were read aloud at Arzamas on the same day they were received; and today, at the last Arzamas hosted by Black Raven [Aleksandr Pleshcheev's nickname], I will convey your derogatory attitude). Vatsuro and Ospovat, eds., “Arzamas,” 1:433. 
tightly knit and effective communication network. ${ }^{40}$ Applying Collins's theory to Arzamas, it is these social interactions - both in the form of meetings and using the technology of writing to exchange information-that creates the network's unique culture.

While its famous membership has made Arzamas a favorite topic of Russian literary scholarship, it is important to remember that the circle's unique culture was part of a minor subculture, set apart even from other literary circles of the time. One product of this subculture was the development of a familiar language so replete with in-references that only members of Arzamas could fully understand their own body of works. The Arzamasians regularly used codenames for each other, and this, combined with their letters' familiarity and their particular assembly of common poetic images, contributed to a culture of exclusivity. Viazemskii's khalat became one of these in-references, a part of network memory that served to bind the group together, even after its dissolution.

For example, while not in code, per se, this excerpt from a September 1825 letter from Pushkin to Viazemskii seems meaningless without intimate knowledge of the circle's in-references: "Милый, мне надоело тебе писать, потому что не могу являться тебе в халате, на разпашку и спустя рукава" (My dear, I'm fed up writing to you because I can't appear to you in my khalat, unbuttoned and slipshod). ${ }^{41}$ Addressed to Viazemskii, the inclusion of a khalat reference takes on additional significant meaning. Mikhail Gronas cites this excerpt as an example of a coded complaint about the political regime, showing the political association of Viazemskii's khalat for the group. ${ }^{42}$ Following Viazemskii's 1817

${ }^{40}$ Mikhail Gronas attributes Pushkin's success as a poet to the viability of this network. On letters and their significance as an early "social network," see Mikhail Gronas, "Pushkin and the Art of the Letter," in Andrew Kahn, ed., The Cambridge Companion to Pushkin (Cambridge, Eng., 2007), 130-42.

${ }^{41}$ Aleksandr Pushkin, Pis $<$ '>ma (Moscow, 1926), 1:159-60.

${ }^{42}$ Gronas, "Art of the Letter," 136-37. 
poem, the khalat took on memetic qualities, changing its connotations depending on context and authorial intent but preserving its evolving semantic meaning through a variety of shifts.

An early khalat reference occurs in a late 1817 or early 1818 speech Zhukovskii delivered at an Arzamasian gathering. Zhukovskii mentions that “Асмодей, распростившись с халатом свободы, лезет в польское платье, поет мазурку и учит польскую азбуку” (Asmodeus [Viazemskii’s Arzamasian alias], having bid his khalat of freedom farewell, climbs into Polish dress, praises the mazurka, and studies the Polish alphabet). ${ }^{43}$ Here the khalat gives way to yet another politically meaningful costume, this time that of "Polish dress." While Viazemskii is being sent to Warsaw against his will, Zhukovskii's blithe quip suggests an alternative to the government uniform: the choice of supporting Polish independence, again implicitly politicizing the khalat image. The "dressing gown of freedom" seems allencompassing, incorporating romantic, artistic, and political freedom-meanings that came to symbolize Arzamas idealistically for its members and which they valued long after the circle's 1818 dissolution. Before the poem's printing, in 1821, the image appeared in poems and writings of those within Viazemskii's circle of friends, spreading virally, even beyond Arzamas's membership roster.

Before I show the memetic evolution of Viazemskii's khalat, some general information about memes would be useful to keep in mind. As I demonstrated in the first part of this article, Viazemskii's khalat, as evoked in "Proshchanie s khalatom," carries an aura of association and meaning that includes the culture of literary process, particular views on the poet's role, the concepts of inspiration and poetic genius, and, more generally, notions of freedom, informality, and private life. These elements were part of early nineteenth-century literary culture, and, particularly, Arzamasian culture, but they became focused around the image of Viazemskii's khalat.

${ }^{43}$ This version is reported in a letter sent from N. I. Turgenev to S. I. Turgenev on January 25, 1818. Vatsuro and Ospovat, eds., "Arzamas," 1:589. 
Memetics relies on the original image's associations and meaning, as well as its potential for evolution as subsequent individuals take up the meme. As Henry Plotkin observes,

Memes are roughly equivalent to ideas or representations, that is, the internal end of the knowledge relationship. ... A selection device, usually a form of language, moves the selected memes about in space and conserves them in time. This combination of differential selection and transmission leads to differential conservation of memes over time, and hence results in changes in meme frequencies in the cultural meme pool in time. Furthermore, memes are not immutable. They change, for whatever reasons, and these changed forms are further subjected to selection, which leads to further changes in the constitution of the meme pool. The result is descent with modification; and what is being modified is the culture itself. ${ }^{44}$

If we consider Plotkin's discussion within the context of Collins's intellectual network, the meme carries with it the information that becomes crucial in the formation of network memory. In the case of Arzamas and Viazemskii's khalat, this memetic transfer contributed to the creation of a particular cultural ethos that bonded the group, as I will show in my discussion of the poems that appeared in the wake of Viazemskii’s, including Del'vig’s “Moia khizhina” (My Hut, 1818) and Pushkin's "Vsevolozhskomu” (To Vsevolozhskii, 1819), "Orlovu” [To Orlov, (819), and "V. L. Davydovy” (To V. L. Davydov, 1821). These poems draw on and embellish Viazemskii's initial khalat image, clearly evoking the spirit of Arzamasian exchange as well as the circle's cultural memory.

While not a member of Arzamas, Del'vig was intimately acquainted with the circle's members and draws on Viazemskii's khalat image in "Moia khizhina." The poem paints a pastoral picture, an idyll in which the poet lives informally with his young, pretty wife.

${ }^{44}$ Plotkin, Darwin Machines, 215-16. 
Когда я в хижине моей

Согрет под стеганым халатом,

Не только графов и князей-

Султана не признаю братом! ${ }^{45}$

(When I am in my hut / Warmed under a quilted dressing gown, / I disavow not only counts and princes- / But also a sultan as my brother!)

From the poem's outset, he marks his position with his khalat, eschewing those of high social rank. He shows his affinity for the dressing-gowned life in rhyming "khalatom" with "bratom" (brother). Later he refers to a time "when [he] was simply a poet" (Kogda ia prosto byl poet), but in this celebration of a simple, bountiful life, his role as poet remains central to his happiness. In the third line, he calls himself "blessed to be a poet" (blazhen poet), and we understand that his poet's mantle is his quilted dressing gown from the first quatrain. Del'vig's peaceful, happy idyll reinforces Viazemskii's khalat as poetic uniform. In setting the domestic "steganyi khalat" (quilted dressing gown) against counts, princes, and a sultan, Del'vig's poet forges a literary position for himself that simultaneously dismisses these social hierarchical roles. In marking the dressing gown as a poetic uniform, Del'vig's poem demonstrates the spread of the khalat meme beyond the bounds of Arzamas.

As Pushkin began to write poems using Viazemskii's khalat, the image developed new accents, although its core remained rooted in the original connotations of freedom and dilettantism. The July 1819 poem "Orlovu," a tribute to Aleksei Orlov, noted hero of the Napoleonic Wars, meditates on the poet's potential in Orlov's military world. Viazemskii's khalat appears in the poem's final section.

\section{В бухарской шапке и в халате}

${ }^{45}$ A. A. Del<'>vig, "Moia khizhina," Polnoe sobranie stikhotvorenii (Leningrad, 1959; hereafter PSS), $122-23$. 
Я буду петь моих богов,

И буду ждать.-Когда ж восстанет

С одра покоя бог мечей,

И брани громкой вызов грянет,

Тогда покину мир полей;

Питомец пламенный Беллоны,

У трона верный гражданин!

Орлов, я стану под знамены

Твоих воинственных дружин;

В шатрах, средь сечи, средь пожаров,

С мечом и с лирой боевой

Рубиться буду пред тобой

И славу петь твоих ударов. ${ }^{46}$

(In a Bukharan cap and dressing gown / I will extol my gods, / And I will wait. When the god / Of swords rises up from his repose, / And the battle's loud call breaks out, / Then I will leave the fields' peace; / Flaming nursling of Bellona, / Loyal citizen of the throne! / Orlov, I will stand under the banner / Of your soldierly brigades; / In tents, amid the fray, among the fires, / With sword and with lyre the battle / Will fight before you / And sing the glory of your blows.)

While here the dressing gown is mentioned alongside a "Bukharan cap," suggesting its eastern origin, it also evokes Viazemskii's and Del'vig's poetic uniform. Pushkin contrasts the peaceful world of poetic inspiration with the violence of the battlefield; his poet exchanges a "gusarskii mundir" [hussar's uniform jacket] for a khalat. This juxtaposition echoes Viazemskii's image of official life as a battleground contrasted with the dreamlike state that the khalat brings. Additionally, the peaceful landscape of "secret

${ }^{46}$ Pushkin, PSS, 2.1:85-86. 
freedom" (s tainoiu svobodoi) to which the poet retreats to create, as suggested by the musical instruments as well as the verb "to extol" or "sing" (pet'), resonates with Viazemskii's poetic reverie, as well as with Zhukovskii's "khalat svobody" (dressing gown of freedom) ${ }^{47}$ In both cases, the khalat is instrumental as a conduit to this state of creative inspiration. While Pushkin's poet agrees to fight under Orlov's banner in the poem's conclusion, he will continue to fight as a poet, with lyre alongside sword, and singing.

In November 1819, Pushkin wrote "Vsevolozhskomu" for Nikita Vsevolozhskii, the host of the literary and political circle Zelenaia lampa (The Green Lamp, active from 1819 to 1820). Zelenaia lampa was formed after Arzamas's dissolution, and Pushkin and Del'vig were members of the new circle. "Vsevolozhskomu" details the activities of a young society buck, freshly arrived in Moscow. Like Viazemskii's poet in "Proshchanie s khalatom," Pushkin's poet conflates formal society life with artificiality. Viazemskii's poem links society life with duty and his poetic life at home with leisure and, by extension, idleness; Pushkin's poem, on the other hand, plays with the idea of "leisure" in a formal society setting. The "pompous Idleness" (vazhnoe Bezdel'e) that Pushkin depicts is called leisure but characterized by tedium, as we see in the final image ("Boredom held with the cards in their hands" [Skuku s kartami v rukakh]). Following this playful indictment of gentry pursuits, Pushkin's poet gives a lengthy description of the pleasures of a life lived freely, which involve drinking, carousing, and womanizing. However, for our purposes, it is notable that the friends who usher in this new lifestyle come wearing dressing gowns.

В густом дыму ленивых трубок,

В халатах, новые друзья

Шумят и пьют! $!^{48}$

${ }^{47}$ Ibid.

${ }^{48}$ Pushkin, 2.1:101-3. 
(In the thick smoke of lazy pipes, / In dressing gowns, new friends / Make noise and drink!) Although Pushkin's poem does not meditate on artistic creation as Viazemskii's does, the life that he advocates mirrors Viazemskii's description of Anacreon's. In this context, Pushkin's khalat takes on the connotations of Viazemskii's as well as Del'vig's. While, as a poetic symbol, the khalat here could simply demarcate those involved in leisure pursuits, these "new friends" are wearing the older Arzamasian uniform, Viazemskii's khalat, and in so doing, show their break with formal society and acceptance of Pushkin's "life lived for oneself," claiming the mantle of Zhukovskii's "khalat svobody."

In 1820, Pushkin wrote a third poem that uses Viazemskii’s image of the khalat, "V. L.

Davydovu," but grafts a more overtly political meaning onto the garment, building on the image of the poet in battle seen in "Orlovu." Iurii Lotman remarks on the close ties between Pushkin's poetry and the Decembrists' circle during this period:

Political lyrics, created by the poet at this time, identified his special position in the Decembrists' circle. [Some] poems ... expressed the close connection between Pushkin and the political conspirators. However, in even greater measure, the messages of the poems "V. L. Davydovu" ... or "Generalu Pushchinu" [To General Pushchin] . . . spoke to this. While the first group represented agitational-political poems addressed to a broad audience, these other poems were furtive messages from one conspirator to another. They were written in a language of allusions, political cryptograms (in the first case based on the conventional catchwords of a friendly circle of political confederates ... .). ${ }^{49}$

We see this use of "conventional catchwords of a friendly circle" in the poem's conclusion, especially, as Pushkin evokes Viazemskii's khalat, an image well known to the poet's circle. The poem ends,

Вот эвхаристия [другая],

${ }^{49}$ Iu. M. Lotman, Aleksandr Sergeevich Pushkin: Posobie dlia uchashchikhsia (Leningrad, 1983), 85. 
Когда и ты, и милый брат,

Перед камином надевая

Демократической халат,

Спасенья чашу наполняли

Беспенной, мерзлою струей,

И за здоровье тех и той

До дна, до капли выпивали!. . .0

(Here, the Eucharist [of a different kind], / When you and my dear brother / Before the fireplace wearing / The democratic dressing gown / Filled the cup of salvation / With a frothless, frozen stream / And drank to the health of / these and that one / To the bottom, to the last drop!... $)^{51}$

The poem does away with poetic reverie and artistic creation, but the image of the "democratic dressing gown" (demokraticheskoi khalat) preserves the ideas that the khalat has come to embody: freedom, truth, and idealism. Significantly, the rhyme "brat" [brother] and "khalat" is used here, echoing Del'vig and, ultimately, Viazemskii. However, in calling the dressing gown "democratic," Pushkin more overtly politicizes the image. In cryptically evoking the Carbonari, a secret revolutionary society based in Italy, in the phrase "te i ta" (these and that one), the poet includes the rebellious poet Lord Byron in his friendly

${ }^{50}$ Pushkin, 2.1:179. Emphases in the original.

51 "These and that one" is a veiled reference to revolutions going on around the time the poem was written. The poem's annotations include the explanation, “These and that one [Te i ta] are the Italian Carbonari who led the Neapolitan revolution in July 1820. In March 1821, Austrian forces suppressed the uprising in Naples. That one $[t a]$ is political freedom [politicheskaia svoboda].” B. V. Tomashevskii, "Primechaniia," A. S. Pushkin, Polnoe sobranie sochinenii v desiati tomakh (Leningrad, 1977), 2:359. However, in another scholarly edition of Pushkin's poetry, "ta" is identified as "the bourgeois revolution in Spain, 1820-1823.” A. S. Pushkin, Sochineniia v trekh tomakh (Moscow, 1962), 1:460. 
Arzamasian circle. Byron had been inducted into the Carbonari in August 1820 and Pushkin admired the poet greatly, especially during the early 1820 s, when he was introduced to the English poet's works and subsequently tried to learn English. Pushkin also owned a portrait of Byron wearing a dressing gown. ${ }^{52}$ In "V. L. Davydovu," Pushkin reinforces the allusive power of Viazemskii's khalat, creating a poetic uniform that can be used to identify political sympathizers. Read as an extension of this memetic khalat, Pushkin's “democratic dressing gown” becomes a significantly richer and more meaningful poetic image.

In her recent study, Maria Maiofis argues that the Arzamasians conceived of themselves as patriots who aspired to advise Alexander I on internal and foreign affairs during what they saw as a crucial time for change. According to Maiofis, the reform of language and literature was only part of the societal reform the members sought, as can be seen in the fact that most of them served at the College of Foreign Affairs under Count Ioann Kapodistriia and were enthusiastic participants in what she terms "the Russian modernization project." ${ }^{\text {53 }}$ This included the gradual introduction of constitutional laws to the Russian empire and the abolition of serfdom — political reform goals that have at their root the notions of freedom and democracy that entered Russia from western Europe in the wake of the Napoleonic Wars.

Perhaps not surprisingly, the khalat image also acquired these connotations. Viazemskii's original khalat transformed into the "khalat svobody" in Zhukovskii's earlier Arzamasian speech, and we see it change again into the "demokraticheskoi khalat" here in Pushkin's later poem. As we see in the meanings that Viazemskii's khalat accumulates in just these few works, the image's memetic quality altered its meaning significantly while preserving its connotation within network memory. The khalat meme took on

${ }^{52}$ On Byron's politics and reception in Russia, see Nina Diakonova and Vadim Vatsuro, “"No Great Mind and Generous Heart Could Avoid Byronism': Russia and Byron," in Richard Cardwell, ed. The Reception of Byron in Europe, (London, 2004), 2:333-52.

${ }^{53}$ See Maiofis, Vozzvanie k Evrope, esp. 18-27, 691-98. 
a life of its own, transferred through individuals, and became a way of viewing the world, binding together the Arzamasian intellectual network, even after Arzamas ceased to exist. ${ }^{54}$

This article has looked at the khalat's intertextual influences and extratextual influence, as well as its circulation in the Arzamasian correspondence, in the circle's documents, and in other poems that use the image, taking it beyond the bounds of Arzamas. From here, I will discuss some specific moments in the history of Viazemskii's poem's circulation, both textual and memetic. These episodes raise issues relevant to literary-circle information technologies in the late 1810 s and early 1820 s and, in particular, the extended literary process, continuing on after creation and initial dissemination through copying, circulation, and publication.

"Proshchanie s khalatom" appears twice in Pushkin's notebooks. ${ }^{55}$ Pushkin attended the areopagus where Turgenev read the poem, and copied it afterwards. ${ }^{56}$ Copying or reproducing a poem from an oral source led to frequent deviations from the original. In Pushkin's copies, for example, there are many punctuation and capitalization differences, though no major differences in word choice. Arzamasian

${ }^{54}$ This supports anthropologist Robert Aunger's theory that memes go beyond cultural selection theory as an additional causal force for culture to take on a life of its own and transmit itself through individuals. See Robert Aunger, The Electric Meme: A New Theory of How We Think (New York, 2002), 52-58. ${ }^{55}$ Many thanks to Valery Vyugin of the Institute of Russian Literature (Pushkin House) for his generous help in finding the two copies of "Proshchanie s khalatom" in Pushkin's notebooks and comparing them against the versions printed in Rukoiu Pushkina: Nesobrannye i neopublikovannye teksty (Leningrad, 1935), 478-80.

${ }^{56}$ For an exact timeline of Pushkin's entry into and involvement in Arzamas in the summer and early fall of 1817, see Oleg Proskurin, "Kogda zhe Pushkin vstupil v Arzamasskoe obshchestvo? (Iz zametok k teme 'Pushkin i Arzamas')” Toronto Slavic Quarterly 14 (Fall 2005): n.p. 
letters suggest that Pushkin had committed the poem to memory ${ }^{57}$ In the late eighteenth and early nineteenth centuries, copying poetry into notebooks and albums was an important method of both preservation and transference. ${ }^{58}$ While Pushkin's were intended as working notebooks, albums crossed the divide between public and private. Ostensibly for private use, they became public collective creations, allowing writers and their audience to preserve and share literary works. ${ }^{59}$ Pushkin's copies of "Proshchanie s khalatom" are examples of relatively clean copies, with only minor differences from the original. In other cases, however, copying mistakes and genuinely misheard or misremembered phrases contributed to the inevitable circulation of different versions of a single poem. One solution to this problem was printing. ${ }^{60}$

${ }^{57}$ In a letter dated July 22, 1818, Viazemskii wrote Turgenev to ask for manuscripts of two of his poems, "Proshchanie s khalatom" and "Vecher na Volge." Turgenev answered on August 7 that he would find them or would have Pushkin reproduce them from memory Viazemskii, Ostaf<'> evskii arkhiv, 1:109, 1:113. On Pushkin's friendship with Viazemskii and its literary significance, see D. P. Ivinskii, Kniaz P. A. Viazemskii i A. S. Pushkin: Ocherk istorii lichnykh i tvorcheskikh otnoshenii (Moscow, 1994).

${ }^{58}$ On the variety of manuscript texts and their uses during the late eighteenth and early nineteenth centuries, see Abram Reitblat, 'Pis <'>mennaia literature v Rossii v XIX veke, ee sotsiokul<'>turnye funktsii i chitateli," in Damiano Rebecchini and Raffaella Vassena, eds., Reading in Russia: Practices of Reading and Literary Communication, 1760-1930 (Milan, 2014), 79-98, esp. 87-93.

${ }^{59}$ On the function of albums, see Justyna Beinek, "Making Literature in Albums: Strategies of Authorship in Pushkin's Day," Toronto Slavic Quarterly 31 (Winter 2010), and “'Portable Graveyards': Albums in the Romantic Culture of Memory," Pushkin Review 14 (2011): 35-62.

${ }^{60}$ On the development of Russian print culture, see Miranda Remnek, ed., The Space of the Book: Print Culture in the Russian Social Imagination (Toronto, 2011). Especially relevant chapters include George Gutsche, "Dinner at Smirdin's: Forces in Russian Print Culture in the Early Reign of Nicholas I," 54-81, 
Printing a poem provided, in theory, an authoritative version. While poets did continue to revise their work even after publishing, leading to multiple print versions, printing a poem nonetheless created a non-ephemeral version. ${ }^{61}$ As we have seen, "Proshchanie s khalatom" and its attendant dressing gown image traveled widely through the channels of the Arzamasian intellectual network. From the initial letter to Turgenev, to Turgenev's notebook, to the poem's first public reading at the Arzamasian areopagus, to Pushkin's notebooks and memory, Viazemskii's poem was a product of Arzamasian technological production. Furthermore, its main image — the memetic khalat—also circulated, appearing in works by Zhukovskii, Del'vig, and Pushkin. The rich extratextual life of the poem and its central image was possible because the Arzamasian network was organized to promote intellectual exchange through interaction: copying manuscripts, sharing ideas and lyrics in correspondence, and reading work at forums such as the areopagi. Although the Arzamasians did engage in several printed journal projects to facilitate their works' circulation, the print medium would not become a primary method of information transfer until later in the century. ${ }^{62}$

and Joseph Peschio and Igor $<$ ' $>$ Pil $<$ '>shchikov, "The Proliferation of Elite Readerships and Circle Poetics in Pushkin and Baratynskii (1820s-1830s), 82-107.

${ }^{61}$ For an example of this, see I. A. Pil<'>shchikov and J. Peschio's textological project, "Stikhotvornye teksty iz arkhiva obshchestva 'Zelenaia lampa," Pushkin Review 15 (2012): 53-95.

${ }^{62}$ On the Arzamasians' journal projects, and other journals from the 1810s and '20s, see William Mills Todd, III, "Periodicals in Literary Life of the Early Nineteenth Century," in Deborah Martinsen, ed., Literary Journals in Imperial Russia, (Cambridge, Eng., 1997), 37-63, esp. 38-42. Todd writes, "Four brave projects for an Arzamasian journal (1818-24) did not proceed past the stage of tentatively assigning responsibilities to the society's members. Government discouragement played some part in this (the censorship was reluctant to license new periodicals), but much of the fault rested with the group's naïve 
In the late 1810 s and early 1820 s, a tension between literary culture and the professionalization of literature emerged. Authorship carried great value in the literary circle or salon setting, which was based in high society and organized around a network of members united through bonds of family and friendship. For those in the network, printing provided an opportunity for further in-references and injokes but also enabled outsiders to interact with and, in some cases, appropriate a text without knowing the poem's layered meanings. Once "Proshchanie s khalatom" was copied out from Viazemskii's letter, Viazemskii no longer had complete agency over his text. Pushkin copied it, changing minor details. Del'vig and Zhukovskii interpreted Viazemskii's khalat, contributing to its memetic transfer. And finally, when Viazemskii wrote to Turgenev for a copy of the poem, he was offered a version different from his original, one modified ever so slightly through its circulation.

In 1821, "Proshchanie s khalatom" was printed in the journal Syn otechestva (The Son of the Fatherland). Shortly afterward, in 1823, Nikolai Iazykov wrote the poem "K khalatu" (To My Dressing Gown). While his poem was obviously inspired by Viazemskii's original, Iazykov was too young to participate in Arzamas or be as intimate with the circle's members as Del'vig. Iazykov appropriates both Viazemskii's working title ("K khalatu") and the distinctive "khalat svobody" image from Zhukovskii's speech. A joyful ode to the khalat, "K khalatu" revels in the freedom the garment grants the poet, although it seems derivative. As Merkel observes, in Iazykov's poem, "the theme of xalat has become a bit too programmatic, too fixed. [Earlier khalat iterations] were all associated with the true romantic genius; however, Iazykov's avtorskii xalat is essentially a prescribed garment, the predictable mode of dress for the author." ${ }^{93}$

and condescending attitude towards the material aspects of literary dissemination, without which literature would remain a matter of oral recitation and hand-written texts" (40-41).

${ }^{63}$ Merkel, “The Romantic Culture of Xalatnost<'>,” 175. 
Iazykov's poem pays tribute to Viazemskii's khalat, but in so doing merely imitates its earlier iterations; here the dressing gown image does not acquire new layers of meaning. Iazykov's failure to evolve the khalat meme may be due to his position outside the network. While Viazemskii's intellectual network included individuals from outside Arzamas, such as Del'vig, his network's membership did not automatically comprise all those engaging in literary salon life, all writers, or even all poets. The episode shows us that the network existed independently from expected societal ties; its bonds were reinforced through interaction rituals, moments of information exchange among its members. While Del'vig was not a member of Arzamas, he was closely linked with the circle through social gatherings and correspondence and so understood the khalat's layered meanings. Iazykov, on the other hand, had access to "Proshchanie s khalatom" but did not have access to the full register of nuances and in-references that made up Arzamasian cultural memory surrounding the dressing gown image. Nevertheless, in writing "K khalatu," Iazykov signaled that he wanted to engage with the intellectual network.

For those within the network, the khalat became a symbol that nostalgically evoked Arzamas's "innocent" years, when the happy brotherhood of dilettante-poets and thinkers felt free to engage in literature for its own sake. In Del'vig's epigram from the mid-1820s (published in his verse collection of 1829), the khalat becomes the marker of a certain way of viewing the world that, at the time, existed only in Arzamasian cultural memory.

Мы не смерти боимся, но с телом расстаться нам жалко:

так не с охотою мы старый сменяем халат. ${ }^{64}$

(We are not afraid of death, but with the body we are sorry to part: / Just as we reluctantly shed the old dressing gown.)

${ }^{64}$ Del<'>vig, PSS, 194. 
Here he evokes Viazemskii's idealistic yet sorrowful khalat, his own pastoral khalat, and Pushkin's quixotic khalat. ${ }^{65}$ Yet, his lines effect a somber tone, a mood echoed in Viazemskii’s late poetry. For both Del'vig in the mid-1820s and Viazemskii in the 1870s, the khalat symbolizes an era that is past and cannot be recovered, one that exists in the collective memory of the intellectual network.

This article's epigraph, from Viazemskii’s 1877 poem “Zhizn’ nasha v starosti—iznoshennyi khalat," describes the poet's nostalgia for his old life. The khalat is a symbol of his poetic experience as well as a uniform connoting previous ideals: honor, authenticity, and old friendships.

Жизнь наша в старости—изношенный халат:

И совестно носить его, и жаль оставить;

Мы с ним давно сжились, давно как с братом брат;

Нельзя нас починить и заново исправить.

(Our life in old age is a worn-out dressing gown: / We are ashamed to wear it, but sorrowful to abandon it; / We long ago got used to each other, long ago as a brother to a brother; / We cannot be mended and nor restored anew.)

The aging khalat, like the aging poet, is worn out and faded but carries memories of a vibrant past, its Golden Age connotations still vividly alive. The poet concludes that the khalat is a costume of honor and should be worn as proudly as a veteran soldier wears his tattered, battle-worn cloak.

Ещё люблю подчас жизнь старую свою

С её ущербами и грустным поворотом,

И, как боец свой плащ, простреленный в бою,

Я холю свой халат с любовью и почётом.

${ }^{65}$ On Nikolai Polevoi's poem “Skhodstvo" (Similarity, 1832) and its satire of Del<'>vig's epigram and Viazemskii's khalat image, see Merkel, "The Romantic Culture of Xalatnost<'>," 186-98. 
(I still sometimes love my old life / With its drawbacks and melancholy turn, / And, like a warrior his cloak, shot through in battle, / I revere my dressing gown with love and respect.)

The young poet's khalat, in 1817 , is a wondrous robe that enables poetic inspiration and authorial power. The aging poet's khalat, sixty years later, is a relic of a life past. Viazemskii, writing in 1817, sought solace among his Arzamasian brother-poets, a happy, vibrant company engaged in literary exchange with one another. Writing in 1877, Viazemskii was a preromantic poet who had outlived romanticism. His friends had died, and the khalat, for him, evoked not only his own youth but also his memory of their poetic communion.

Viazemskii's khalat is an image of his epoch. Its roots lie in ideals of intellectual freedom and carefree dilettante literary production. As his poem journeys through the information channels of his day—written out in letters, read aloud at gatherings, transferred into notebooks — it becomes enshrined as a meme in the cultural memory of Arzamas, a symbol of the circle's most valued principles. Taking Viazemskii's "Proshchanie s khalatom" as a case study for the functioning interrelationships of early nineteenth-century Russian information technologies leads us to reconceive the notion of "publication." Informal circulation was superior to print for the Arzamasians' kind of literary culture, characterized by meetings, familiar letters, and carefully recorded and preserved protocols. Indeed, none of the poems discussed in this article were printed before they were distributed.

This looseness in the concept of publication is embedded within the literary dilettante culture but prompts us to reconsider the reasons behind the rise of print as a primary means of distribution later in the century. As twenty-first-century literary critics, we often assume the domination of print, of thinking of texts not in terms of their creation dates but their publication dates. As Viazemskii's khalat demonstrates, however, the rise of print was an organic development that represents only one part of the tension between the value given to different modes of production and distribution in early nineteenth-century Russia. Far more important for the eventual rise of a literary profession in Russia was the development of literary 
circles. These high-functioning intellectual networks provided the foundation for the dynamism that fuelled professional literature in Russia and eventually led to the development of print projects based on the literary-circle model but taking into consideration a broader audience, such as circulating libraries, almanacs, and thick journals. However, crucial to the development and bonding of these networks were the smaller, seemingly ephemeral information technologies. These technologies facilitated social interaction when members were apart as well as the rise of coded poetic images laden with meaning, like Viazemskii’s khalat. 